\title{
The Implementation of the Strategy of Marketing Management through a SWOT Analysis with the Matrix of IFE, EFE and IE
}

\author{
Ara Fathia Az Zahra ${ }^{*}$, Wahyudin Wahyudin ${ }^{2}$, Billy Nugraha ${ }^{3}$ \\ ${ }^{1,2,3}$ Industrial Engineering Department, Universitas Singaperbangsa Karawang, Karawang \\ *Koresponden email: arafathia036@gmail.com
}

Diterima: 30 Desember 2020

Disetujui: 2 Maret 2021

\begin{abstract}
The level of competition is usually influenced by a variety of factors such as: promotions, services, security and others. This study aims to analyze the implementation of the strategy of marketing management SME snacks. Although it already has a fairly large market share, but the bare possibility of the presence of competitors engaged in the same field. Then the right strategy is to use the analysis of strength, weaknesses, opportunities and threat (SWOT). In addition, with the approach of matrix internal factor evaluation (IFE), matrix external factor evaluation (EFE) and the matrix internal external (IE). Renewal in the research is the use of the IFE, EFE and IE matrix. This is so that the results of the assessment can determine the position and strength of the business. Then the results of the study show that SME snacks have 8 strength, 7 weaknesses, 6 opportunities and a 5 threat. In addition, the results of the IFE matrix is weighted by 2.74 this show is in the position of the average. While the results of the EFE matrix weighted by 3.01 it is shown to be in a strong position. While the results of the IE matrix is in quadrant II, it is within the scope of a strategy to growth and nurture (growth and build).
\end{abstract}

Keywords: marketing management, strength weaknesses opportunities and treats, internal factor evaluation, external factor evaluation, internal external

\begin{abstract}
Abstrak
Tingkat persaingan biasanya dipengaruhi oleh berbagai faktor seperti: promosi, pelayanan, keamanan dan lain-lain. Penelitian ini bertujuan untuk menganalisis implementasi strategi manajemen pemasaran UKM Makanan Ringan. Walaupun sudah memiliki pangsa pasar yang cukup luas, tapi tidak bertutup kemungkinan adanya kompetitor yang bergerak dalam bidang yang sama. Maka diperlukan strategi yang tepat yaitu menggunakan analisis strength, weaknesses, opportunities dan threat (SWOT). Selain itu dengan pendekatan matriks internal factor evaluation (IFE), matriks external factor evaluation (EFE) dan matriks internal external (IE). Pembaharuan dalam penelitian yang dilakukan adalah penggunaan matriks IFE, EFE dan IE. Hal ini agar hasil penilaian dapat menentukan posisi dan kekuatan bisnis. Hasil penelitian menunjukkan bahwa UKM Makanan Ringan memiliki 8 strength, 7 weaknesses, 6 opportunities dan 5 threat. Selain itu hasil dari matriks IFE terbobot sebesar 2,74 hal ini menunjukkan berada pada posisi rata-rata. Sementara hasil dari matriks EFE terbobot sebesar 3,01 hal ini menunjukkan berada pada posisi kuat. Sedangkan hasil dari matriks IE berada pada kuadran II hal ini dalam lingkup strategi tumbuh dan membina (growth and build).
\end{abstract}

Kata Kunci: marketing management, strength weaknesses opportunities and treats, internal factor evaluation, external factor evaluation, internal external

\section{Introduction}

The public interest in the consumption of complementary foods or can be said a snack is very high $[1,2]$. The level of enthusiasts of snack food is characterized by the increasing number of businesses a snack that is growing in Indonesia. Starting from the home industry, SME/MSME up to large factories a lot of operate. In the food business is increasingly tight competition. Because basically the public will get bored when not applied strategies or innovations provided [3]. Products especially pastries from year to year the level of the number of competitors is increasing. In addition, diverse types of pastries are more varied. This is evident from the number of business units of the food industry which increased from year to year. As in Table 1.

Cake Shop XYZ already has a large enough market share. But the bare possibility of the presence of competitors engaged in the same field. The level of competition is usually influenced by various factors such as: promotions, services, security and others $[5,6]$. So to the demands of its own for any business [7]. 
Table 1. The number of units of industrial enterprises large medium

\begin{tabular}{clrrr}
\hline KBLI & \multicolumn{1}{c}{ Description KBLI } & 2015 & 2018 & Difference \\
\hline 10 & The Food Industry & 6.453 & 7.723 & 1.270 \\
11 & The Beverage Industry & 422 & 687 & 265 \\
12 & Industrial Processing of Tobacco & 940 & 772 & $(168)$ \\
13 & The Textile Industry & 2.612 & 3.139 & 527 \\
14 & Apparel Industry & 2.360 & 2.986 & 626 \\
15 & Leather Industry, Leather Goods and Footwear & 738 & 1.083 & 345 \\
16 & Industrial Wood, Articles of Wood and Cork & 1.220 & 1.596 & 376 \\
17 & Industry Paper and Goods of Paper & 508 & 919 & 411 \\
18 & Industry Printing and Reproduction of Recorded Media & 616 & 1.142 & 526 \\
19 & Industrial Products from Coal and Oil Refining & 81 & 165 & 84 \\
20 & The Chemical Industry and Goods from Chemicals & 1.075 & 1.523 & 448 \\
21 & The Pharmaceutical, Drug Products and Traditional Medicine & 256 & 372 & 116 \\
\hline
\end{tabular}

$$
\text { Source: [4] }
$$

Especially the Cake Shop XYZ to be able to maintain customer loyalty in order to remain loyal to its products. Moreover, it can get the brand products can build an image that is positive for the customer [8]. Then from it. This study aims to analyze the implementation of the strategy marketing management Cake Shop XYZ. Then the required strategy marketing management a systematic. The right strategy is to use the analysis of strength, weaknesses, opportunities and threat (SWOT). In addition, with the approach of matrix internal factor evaluation (IFE), matrix external factor evaluation (EFE) and matrix internal external (IE).

Renewal of this research is the stages carried out to determine the management strategy is good marketing. Done the SWOT analysis which will analyze accurately in accordance with the data and facts on the ground. After that each result will be assessed through the IFE matrix and EFE. It aims to obtain the sum of the weight value to determine in what position of the business. Then to get the final result done the IE matrix. It is the result of the combined sum of the weights of the value of the matrix IFE and EFE. Once determined it will be known when this Cake Shop XYZ was on what conditions. The contributions made in this study of the strength and position of the business running. This of course can be used as parameters. With the aim that the strength and position of the business can survive in later in the day. Then the results of the study can be used as a parameter to similar businesses.

\section{SWOT Analysis}

SWOT analysis is the identification of the various factors systematically to formulate business strategy. This analysis is based on the logic that can maximize the strength and opportunities. But at the same time can minimize the weaknesses and threats [9]. There are four types of strategies that can be developed with a SWOT analysis [10], as follows:

1. Strategy S-O (Strength-Opportunities), is a strategy that uses the power of internal efforts to get the opportunities that exist outside the business.

2. Strategy W-O (Weaknesses-Opportunities), is a strategy that aims to minimize the weakness of the internal business by taking advantage of opportunities external.

3. Strategy S-T (Strength-Threat), that this strategy the business seeks to avoid or reduce the impact of threats external.

4. Strategy W-T (Weaknesses-Threat), namely a strategy to survive by reducing internal weaknesses and avoid threats.

\section{IFE Matrix}

Matrix Internal Factor Evaluation (IFE) is a tool of strategy formulation are used to evaluate the strengths and weaknesses. In addition it has also become a platform to identify the relationship between the two. Intuitive judgments used in the development of IFE matrix [5]. So the results of the analysis should not be value as evidence that without the gap.

\section{EFE Matrix}

Matrix External Factor Evaluation (EFE) is a tool of strategy formulation are used to evaluate the opportunities and threats. In addition, strategies for evaluating information. Information regarding the economic, social, cultural, demographic, environmental, political, government, legal, technology and competition [5]. So that each study is not in its value as evidence that without the gap. 


\section{IE Matrix}

Matrix Internal External (IE) is useful to position the business in a matrix consisting of 9 quadrants. The IE matrix consists of two dimensions. Two such dimensions, namely the amount of the value of the IFE matrix on the $x$ axis and the amount of the value of the EFE matrix on the $y$ axis [5]. This matrix is grouped into 3 main strategies, namely growth and a build, hold and maintenance and harvest and devest.

\section{Literature Review}

Some of the results of previous research by using SWOT analysis with IFE, EFE and IE. It is as a parameter in the research being conducted, as follows: Research conducted by the Annisa Mayang Indri Astuti and Shinta Ratnawati: From the results of the analysis of the data obtained the total score of the factors of strength, weaknesses, opportunities and threats, respectively obtained by weighting the highest strength of 0.55 , the weight of weakness lines to 0.40 , the weight of the highest odds of 0.55 , and the weight of the highest threat of 0.44 [11]. Research done by Hany Setyorini, Mas'ud Effendi and Imam Santoso: By using the SWOT matrix and Quantitative Strategic Planning Matrix (QSPM), an alternative strategy that is achieved [12]. A study conducted by Umar Mansoor and the Supreme Zulfikri: Where the results of total IFE show of 2.69 and the total EFE shows 3,22 indicating the position of the strong internal and external [13]. The research conducted by Vicky F. Sanjaya, Desy Shelawati, the Barrel Ghati and Berama: Results of the study the culinary business in the Province of Lampung has to 2.94 analysis of IFE matrix, the Total score analysis of the EFE show of 2.75 [14]. Research conducted by Hernando Hermawanto: the Results obtained form the analysis of the internal and external environment of companies and the formulation of business strategy that should be applied to the company [15].

While some of the another study using SWOT analysis with IFE, EFE and IE as follows: Research conducted by Dicki Prayudi and Resti Yulistria: the Results of this study show that the final score after the weighting on the internal analysis as strength is the plot of the organization, while the weakness is the character of human resources [16]. A study conducted by Klara R. A. Yohansyah, Lisbeth Mananeke and Hendra N. Alum: Based on the results of the analysis of IFE matrix is the Score of the 1.3635 and EFE 2,3795 then the results are in pour in the SWOT matrix quantitative 4 quadrant [17]. Research conducted by Nuraida Wahyuni, Daenulhay Kasmin, Evi Febianti and Gusti Imam Bimantara: the Results showed that the combination of 6 chances, 6 threats, 10 strength and 5 weaknesses, achieved 5 tactical strategy [18]. Research conducted by Yuyun Umniyatun: Research about the strategic plan of the business done RSIA SMB produce a score of EFE by 3.8 and a score of IFE amounted to 2,725, so that the known position of the RSIA SMB is located on the cell II which shows the stages of grow and build [19]. Research conducted by Auguar, Muhammad Firdaus and Sahara: an Analysis of internal and external factors each have a score of 2,541 and 3,261 [20].

\section{Material and Methods}

\section{The Identification of the Research Variables}

The identification of the research variables in the form of environment variables internal and external Cake Shop XYZ. Internal variables include: management (planning, organizing, actuating and controlling) and marketing (product, price, place, promotion, process, person, physical evidence, productivity and quality). Variable external form: micro environment (suppliers, customers and competitors), industry environment (threat of product substitution, competition among firms and the threat of new entrants) and the macro environment (demographic, economic, social, political, and technological).

\section{Assumptions Research Data}

Assumptions research data obtained it from some of the results of similar research. It can be used as parameters for the determination of the variables/indicators in analyzing a business. Then the determined variables/indicators that have been mentioned earlier. Of course the variables/indicators are just some of the many variables/indicators that can be examined again.

\section{Types of Research Data}

This research type is qualitative descriptive. This research was conducted by using the descriptive qualitative method, because the authors analyze the business strategy that should be used by the Cake Shop XYZ. The subject of this study is the Cake Shop XYZ by using the SWOT analysis with the matrix of IFE, EFE and IE. The type of data used is qualitative data such as interviews (field studies).

\section{Data Collection Techniques and Sampling}

Data collection techniques used were interviews (field studies). The type of interviews conducted in this research is semi structured interview. In addition, the sampling technique in this study using purposive sampling. The data analysis technique used in this research is the concept of data analysis 
model Milles and Huberman. The first step is data reduction (data reduction), the second step is data display (presentation of data) and the third step is drawing conclusions and verification of data.

Frame of Mind Research

The framework in this research is a result of the development of F. Rangkuti (Rangkuti, 2001). As in Figure 1.

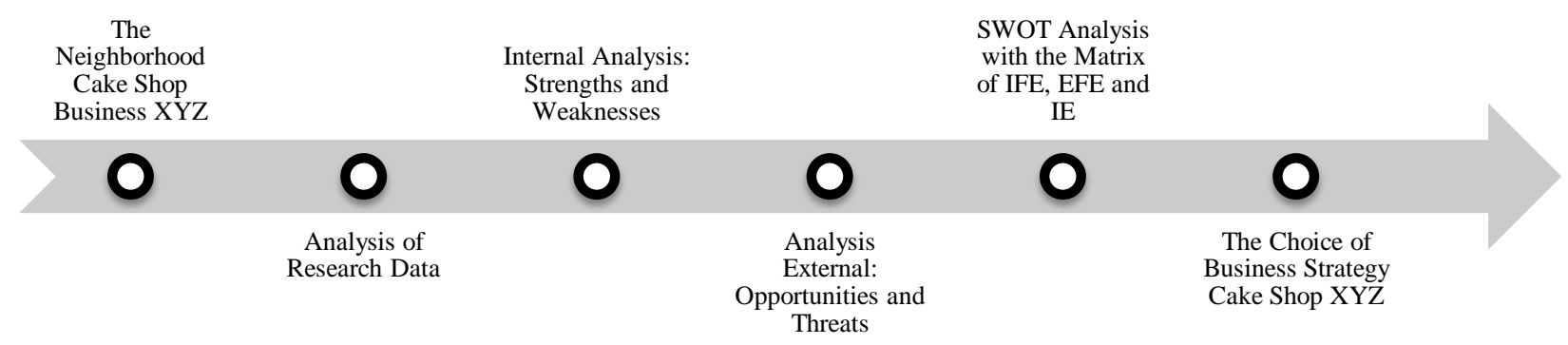

Figure 1. Model development framework research

Source: Research processing results, 2020

\section{Results and Discussion \\ Internal and External Factor}

To be able to formulate a marketing strategy, businesses should pay attention to the aspects of the environment (internal and external) [21,22]. The following is the internal factors (strengths and weaknesses) and external (opportunities and threats) [23, 24]. As in Table 2.

Table 2. Internal (Strengths and Weaknesses) and External (Opportunities and Threats) Factor

\begin{tabular}{|c|c|c|}
\hline \multicolumn{3}{|c|}{ Internal Factor } \\
\hline & Strengths & Weaknesses \\
\hline 1. & Has a skilled workforce. & The lack of promotion of the product. \\
\hline 2 . & Labor live close. & The absence of quality control of the product. \\
\hline 3. & Have certification of halal products. & 3. Production equipment $40 \%$ manual. \\
\hline 4. & Have business licensing is complete. & 4. The structure of business that are less good. \\
\hline 5 . & Have a product with economical price. & 5. Financial of the business has not been good. \\
\hline 6 . & Sales based on business to business. & 6. The lack of strategy of transition of market share. \\
\hline 7. & Communication between the labor good. & 7. Distribution of products only in Brass. \\
\hline \multicolumn{3}{|c|}{ External Factor } \\
\hline & Opportunities & Threats \\
\hline 1 . & The growth in number of the population that fast. & Rising inflation in Indonesia. \\
\hline 2 . & Increase the lifestyle of the people. & The emergence of many other baking products. \\
\hline 3 . & The growth of the market higher. & The increase in raw material prices. \\
\hline 4. & The loyalty of consumers towards the product. & Power consumer purchases decline. \\
\hline 5 . & Have good relationship with suppliers. & 5. The presence of a competitor is easily obtainable. \\
\hline
\end{tabular}

Source: Research processing results, 2020

\section{SWOT Analysis}

There are alternative strategies that will be used by the Cake Shop XYZ, as follows:

1. Strategy S-O (Strength-Opportunities), as follows:

a. Improve marketing of existing products currently on new market.

b. Improve the quality of the product.

c. Improve good relationship with distributors and suppliers.

2. Strategy W-O (Weaknesses-Opportunities), as follows:
a. Improve the organizational structure of the business
b. Control the quality of the product.
c. Boost promotional products.

3. Strategy S-T (Strength-Threat), as follows:
a. Create innovation for new products more popular consumer.
b. Doing the bidding of mutualism with suppliers in order to get the price of raw materials.
c. Observe the trend of food and a minimum of among the people. 
4. Strategy W-T (Weaknesses-Threat), as follows:

a. Increase marketing efforts of the product through promotional activities intensified.

b. Analyze the financial Cake Shop XYZ.

From the results of the alternative strategy above, then processing the data using a SWOT analysis as in Table 3.

Table 3. SWOT Analysis

\begin{tabular}{|c|c|}
\hline $\begin{array}{l}\text { Strengths } \\
\text { (S) }\end{array}$ & $\begin{array}{c}\text { Weaknesses } \\
(\mathrm{W}) \\
\end{array}$ \\
\hline 1. Has a skilled workforce. & $\begin{array}{l}\text { The lack of promotion of the } \\
\text { product. }\end{array}$ \\
\hline 2. Labor live close. & $\begin{array}{l}\text { The absence of quality } \\
\text { control. }\end{array}$ \\
\hline $\begin{array}{l}\text { 3. Have certification of halal } \\
\text { products. }\end{array}$ & $\begin{array}{l}\text { Production equipment } 40 \% \\
\text { manual. }\end{array}$ \\
\hline $\begin{array}{l}\text { Have business licensing is } \\
\text { complete. }\end{array}$ & $\begin{array}{l}\text { The structure of business } \\
\text { organizations that is less } \\
\text { good. }\end{array}$ \\
\hline $\begin{array}{l}\text { 5. Have a product with } \\
\text { economical price. }\end{array}$ & $\begin{array}{l}\text { 5. Financial management of the } \\
\text { business has not been good. }\end{array}$ \\
\hline $\begin{array}{l}\text { 6. Sales based on business to } \\
\text { business. }\end{array}$ & $\begin{array}{l}\text { The lack of strategy of } \\
\text { transition of market share. }\end{array}$ \\
\hline $\begin{array}{l}\text { 7. Communication between the } \\
\text { labor good. }\end{array}$ & $\begin{array}{l}\text { 7. Distribution of products only } \\
\text { in Brass. }\end{array}$ \\
\hline $\begin{array}{c}\text { Strategy } \\
\text { S-O }\end{array}$ & $\begin{array}{c}\text { Strategy } \\
\text { W-O } \\
\end{array}$ \\
\hline $\begin{array}{l}\text { Improve the marketing of the } \\
\text { product in a new market. } \\
\text { 2. Improve the quality of the } \\
\text { product effort. } \\
\text { 3. Improve the relationship with } \\
\text { the suppliers. }\end{array}$ & $\begin{array}{l}\text { Improve the organizational } \\
\text { structure of the business } \\
\text { 2. Control the quality of the } \\
\text { product effort. } \\
\text { 3. Increase product promotion } \\
\text { efforts. }\end{array}$ \\
\hline
\end{tabular}

\begin{tabular}{|c|c|c|}
\hline $\begin{array}{c}\text { Threats } \\
\text { (T) }\end{array}$ & $\begin{array}{c}\text { Strategy } \\
\text { S-T }\end{array}$ & $\begin{array}{c}\text { Strategy } \\
\text { W-T }\end{array}$ \\
\hline $\begin{array}{l}\text { 1. Rising inflation in Indonesia. } \\
\text { 2. The emergence of many } \\
\text { competitor baking products. } \\
\text { The increase in raw material } \\
\text { 3rices. } \\
\text { 4. Power consumer purchases } \\
\text { decline. } \\
\text { The presence of a competitor } \\
\text { 5. product which is easily } \\
\text { obtainable. }\end{array}$ & $\begin{array}{l}\text { 1. Create innovation for new } \\
\text { products that are in demand. } \\
\text { 2. Doing the bidding of } \\
\text { mutualism to the supplier. } \\
\text { 3. Observe the trend of food and } \\
\text { beverage at this time. }\end{array}$ & $\begin{array}{l}\text { 1. Increase marketing efforts of } \\
\text { the product. } \\
\text { 2. Analyze the financial Cake } \\
\text { Shop business XYZ. }\end{array}$ \\
\hline
\end{tabular}

Source: Research processing results, 2020

Alternative strategies were obtained and incorporated into the strategy that has been formulated in the IE matrix, ie grow and develop (growth and build) [25] as follows:

1. The Market Penetration strategy, as follows:

a. Improve the quality of the products ( $\mathrm{S}-\mathrm{O} 2)$.

b. Improve good relationship with distributors and suppliers (S-O 3).

c. Improve the structure of business organizations (W-O-1).

2. The Marketing strategy of the Product, as follows:

a. Improve the marketing of products that are currently on the new market (S O-1).

b. Improve the promotion of the product (W-O 3). 
c. Increase marketing efforts of the product through promotional activities intensive (W-T 3).

3. Product Development strategy, as follows:

a. Control the quality of the product (W-O 2).

b. Doing the bidding of mutualism with suppliers (S-T 2).

c. Observe the trend of food and beverage current (S-T 3).

4. The strategy of Integration, as follows:

a. Create innovation for new products more popular consumer (S T-1).

b. Analyze the financial Cake Shop XYZ (W-T 2).

\section{IFE Matrix}

Processing matrix the internal factor evaluation (IFE) at the Cake Shop XYZ, as in Table 4.

Table 4. The results of IFE matrix

\begin{tabular}{|c|c|c|c|c|}
\hline No. & Internal Factor & Weigth & Rating & Score \\
\hline \multicolumn{5}{|c|}{ Strength } \\
\hline 1. & Has a skilled workforce. & 0,08 & 4 & 0,32 \\
\hline 2. & Labor live close. & 0,06 & 3 & 0,18 \\
\hline 3. & Have certification of halal products. & 0,06 & 3 & 0,18 \\
\hline 4. & Have business licensing is complete. & 0,06 & 3 & 0,18 \\
\hline 5. & Have a product with economical price. & 0,08 & 4 & 0,32 \\
\hline 6. & Sales based on business to business. & 0,09 & 4 & 0,36 \\
\hline 7. & Communication between the labor good. & 0,08 & 3 & 0,24 \\
\hline 8. & The soul of kinship between labor high. & 0,08 & 3 & 0,24 \\
\hline \multicolumn{5}{|c|}{ Weaknesses } \\
\hline 1. & The lack of promotion of the product. & 0,08 & 2 & 0,16 \\
\hline 2. & The absence of quality control on the product. & 0,05 & 2 & 0,01 \\
\hline 3. & Production equipment $40 \%$ manual. & 0,05 & 1 & 0,05 \\
\hline 4. & The organizational structure of the business less well. & 0,05 & 1 & 0,05 \\
\hline 5. & Financial management in business has not been good. & 0,06 & 2 & 0,12 \\
\hline 6. & The lack of strategy of transition of market share. & 0,07 & 2 & 0,14 \\
\hline \multirow[t]{2}{*}{7.} & Distribution of products only in Brass. & 0,05 & 2 & 0,01 \\
\hline & Total & 1 & & 2,74 \\
\hline
\end{tabular}

Source: Research processing results, 2020

Based on Table 4. the above obtained sum of weighted values equal to 2.74 . This shows that the Cake Shop XYZ is located at the average position. However it can be said is still quite strong against the weakness, because the value above 2,50. While the Cake Shop XYZ can leverage the power of owned and able to overcome these weaknesses [26].

EFE Matrix

Processing matrix the external factor evaluation (EFE) at the Cake Shop XYZ, as in Table 5.

Table 5. The results of EFE matrix

\begin{tabular}{|c|c|c|c|c|}
\hline No. & External Factor & Weigth & Rating & Score \\
\hline \multicolumn{5}{|c|}{ Opportunities } \\
\hline 1. & Population growth is very fast. & 0,09 & 3 & 0,27 \\
\hline 2. & Increase the lifestyle of the people. & 0,01 & 4 & 0,04 \\
\hline 3. & Market growth is increasingly high. & 0,01 & 4 & 0,04 \\
\hline 4. & The loyalty of the consumer. & 0,12 & 4 & 0,48 \\
\hline 5. & Have a good relationship with suppliers. & 0,11 & 4 & 0,44 \\
\hline 6. & Have a good relationship with the distributor. & 0,01 & 4 & 0,04 \\
\hline \multicolumn{5}{|c|}{ Threats } \\
\hline 1. & Rising inflation in Indonesia. & 0,07 & 2 & 0,14 \\
\hline 2. & The emergence of many competitors products other cakes. & 0,08 & 1 & 0,08 \\
\hline 3. & The increase in raw material prices. & 0,07 & 2 & 0,14 \\
\hline 4. & Consumer purchasing power decreased. & 0,01 & 2 & 0,02 \\
\hline \multirow[t]{2}{*}{5.} & The presence of substitute products are easily obtained by the consumer. & 0,06 & 1 & 0,06 \\
\hline & Total & 1 & & 3,01 \\
\hline
\end{tabular}


Based on Table 5 the above obtained sum of values weighted by 3.01. This shows that the Cake Shop XYZ was in a strong position. Because it has a number of weighted values of more than 3.00. While the Cake Shop XYZ can take advantage of the opportunities that are owned and able to cope with such threats [27].

IE Matrix

On the $x$-axis the IE matrix, the value of the number of IFE equal to 2.74 and on the y-axis the IE matrix, the value of the number of EFE by 3.01. The results of the IE matrix shows that the Cake Shop $\mathrm{XYZ}$ is on the quadrant II of the matrix IE. The strategies used by the Cake Shop XYZ within pass quadrant II is a strategy to grow and develop (growth and build). Due to the consists of a intensive strategy, such as (market penetration, product marketing, market development and product development) $[28,29]$. In addition, the strategy is integrative, such as the (backward integration, the integration to the front and integration to the horizontal line) [30]. Then the mapping of the IE matrix shows that the Cake Shop XYZ, as in Table 6. below:

Table 6. The Results of IE Matrix

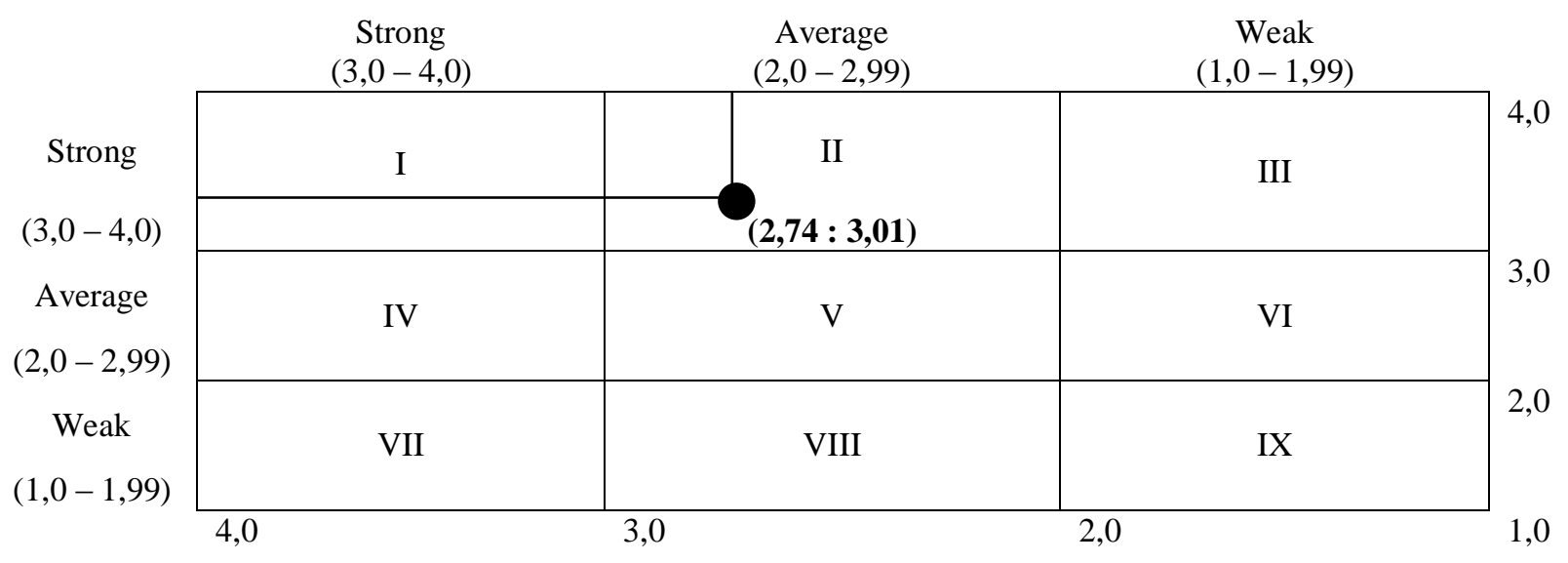

Source: Research processing results, 2020

\section{Conclusion}

The results showed that the Cake Shop XYZ has 8 strength, 7 weaknesses, 6 opportunities and 5 threat. In addition, the results of the IFE matrix is weighted equal to 2.74 this suggests are in the average position. While the outcome of the EFE matrix weighted by 3.01 it is shown to be in a strong position. While the results of the IE matrix is in quadrant II it is within the scope of the strategy to grow and develop (growth and build). Suggestions are made for further research by re-analyzing the factors internal and external that are not examined in this study. Because such factors have a great influence in determining the business strategy that is more appropriate to the future.

\section{Acknowledgment}

My special gratitude goes to Rector, Dean, Study Programme Coordinators of University of Singaperbangsa Karawang, as well as Cake Shop XYZ who have provided support and assistance in the research.

\section{References}

[1] S. Assauri, Manajemen Pemasaran, 1st ed., Jakarta: Rajawali Pers, 2013.

[2] L. J. Gitman, Principles of Managerial Finance, 11th ed., New Jersey: Pearson International Inc., 2006.

[3] F. Tjiptono, Pemasaran Strategik, 1st ed., Yogyakarta: Andi Offset, 2012.

[4] Kementrian Perindustrian - Republik Indonesia (Kemenperin - RI), "Laporan Kinerja Kementrian Perindustrian Tahun 2018," in Laporan Kinerja Kementrian Perindustrian Tahun Anggaran 2018, S. Wasisto, Ed., Jakarta, Biro Perencanaan Sekretariat Jenderal, 2019, p. 23.

[5] F. R. David, Strategic Management: Concepts and Cases, 13th ed., New Jersey: Pearson Education 
Inc., 2011.

[6] Suprayanto and Rosad, Manajemen Pemasaran, 1st ed., Bogor: In Media, 2015.

[7] L. R. Jauch and W. F. Glueck, Manajemen Strategis dan Kebijakan Perusahaan, 2nd ed., Jakarta: Erlangga, 1988.

[8] T. L. Saaty, Pengambilan Keputusan bagi Para Pemimpin dalam Ir. Kirti Peniwati, MBA., 2nd ed., Jakarta: PT. Gramedia, 1993.

[9] F. Rangkuti, Analisis SWOT Teknik Membedah Kasus Bisnis, 1st ed., Jakarta: PT. Gramedia Pustaka Utama, 2001.

[10] Noor, Strategi BAru Manajemen Pemasaran, 1st ed., Yogyakarta: Amara Books, 2014.

[11] A. M. I. Astuti and S. Ratnawati, "Analisis SWOT dalam Menentukan Strategi Pemasaran (Studi Kasus di Kantor Pos Kota Magelang 56100)," Jurnal Ilmu Manajemen, vol. XVII, no. 2, pp. 58-70, 2020.

[12] H. Setyorini, M. Effendi and I. Santoso, "Analisis Strategi Pemasaran Menggunakan Matriks SWOT dan QSPM (Studi Kasus: Restoran WS Soekarno Hatta Malang)," Industria: Jurnal Teknologi dan Manajemen Agroindustri, vol. V, no. 1, pp. 46-53, 2016.

[13] U. Mansur and A. Zulfikri, "Strategi Mempertahankan Keunggulan Kompetitif PT Jayamandiri Gemasejati - Sukabumi," Jurnal Bisnisman: Riset Bisnis dan Manajemen, vol. II, no. 2, pp. 47-58, 2020.

[14] V. F. Sanjaya, D. Shelawati, L. Ghati and Berama, "IFE EFE dan Grand Strategy Industri Kuliner," Revenue: Jurnal Manajemen Bisnis Islam, vol. I, no. 2, pp. 159-170, 2020.

[15] H. Hermawanto, "Analisis Strategi Bisnis pada CV. Sukses Bersama Sejahtera," Agora, vol. V, no. 3, pp. 1-5, 2017.

[16] D. Prayudi and R. Yulistria, "Penggunaan Matriks SWOT dan Metode QSPM pada Strategi Pemasaran Jasa Wedding Organizer; Studi Kasus pada UMKM Gosimplywedding Sukabumi," Jurnal Maksipreneur: Manajemen, Koperasi, dan Entrepreneurship, vol. IX, no. 2, pp. 224-240, 2020.

[17] K. R. A. Yohansyah, L. Mananeke and H. N. Tawas, "Penentuan Strategi Pemasaran Berdasarkan Analisa SWOT pada Produk Amanah di PT. Pegadaian (Persero) CP. Manado Utara," Jurnal EMBA, vol. VIII, no. 4, pp. 885-894, 2020.

[18] N. Wahyuni, D. Kasmin, E. Febianti and G. I. Bimantara, "Quantitative Strategic Planning Matrix Pemasaran Air Minum dalam Kemasan," Performa: Media Ilmiah Teknik Industri, vol. XIX, no. 1, pp. 39-48, 2020.

[19] Y. Umniyatun, "Penyusunan Rencana Strategis Bisnis pada Rumah Sakit Swasta di Jakarta," Arkesmas, vol. III, no. 1, pp. 42-49, 2018.

[20] Auguar, M. Firdaus and Sahara, "Pengembangan Strategi PT ABC Niaga di Industri Distribusi Gas," Jurnal Aplikasi Bisnis dan Manajemen, vol. III, no. 3, pp. 373-383, 2017.

[21] M. Awais and T. Samin, "Advanced SWOT Analysisof E-Commerce," International Journal of Computer Science, vol. IX, no. 2, pp. 569-574, 2012.

[22] S. Brad and E. Brad, "Enhancing SWOT Analysis with TRIZ-based Tools to Integrate Systematic Innovation in Early Task Deign," Procedia Engineering, vol. I, no. 131, pp. 616-625, 2015.

[23] A. Arshad, M. F. Noordin and R. B. Othman, "A Synthesis on SWOT Analysis of Public Sector Healthcare Knowledge Management Information Systems in Pakistan," International Journal of Advanced Computer Science and Application, vol. VIII, no. 8, pp. 130-136, 2017.

[24] S. Ghazinoory, M. Abdi and M. Azadegan-Mehr, "SWOT Methodology: A State-of-the-Art Review for the Past, a Framework for the Future," Journal of Business Economics and Management, vol. XII, no. 1, pp. 24-48, 2011.

[25] D. O. Madsen, "SWOT Analysis: A Management Fashion Perspective," International Journal of Business, vol. XVI, no. 1, pp. 39-56, 2016.

[26] H. P. Nangoy and F. Samopa, "Strategic Planning of Information Systems and Technology at Company X," International Journal of Education and Research, vol. V, no. 1, pp. 119-126, 2017.

[27] D. Oreski, "Strategy Development by Using SWOT - AHP," TEM Journal, vol. I, no. 4, pp. 283-291, 
2012.

[28] B. Phadermrod, R. M. Crowder and G. B. Wills, "Importance-Performance Analysis based SWOT Analysis," International Journal of Information Management, vol. I, no. 44, pp. 194-203, 2019.

[29] T. S. Tambunan, "SWOT Analysis for Tourism Development Strategy of Samosir Regency," The International Journal of Applied Business, vol. IV, no. 2, pp. 90-105, 2020.

[30] Yunita, "Business Feasibility Research in Opening Leraning Centre at Balaraja based on SWOT and AHP Method," Journal of Applied Information, Communication and Technology, vol. VI, no. 1, pp. 21-27, 2019. 